\title{
ISLAM AND CIVILISATIONAL RENEWAL: THE CASE FOR "SACRED SCIENCE”
}

\author{
Abdul Rashid Moten*
}

\begin{abstract}
The Islamic or Muslim civilisation was once at an incomparable peak in terms of all possible indicators of development. But a destruction of the spirit of inquiry and original research so distinctly associated with civilisational development served to sow the seeds of decay and render it easy prey for colonial exploitation. Confronted with a world dominated by Western science and technology, Muslim scholars have been searching for ways to regain their freedom, control their collective lives and link their past to the future. Some opted for a "secularisation thesis", others advocated liberalisation, still others advocated adoption of science since the Qur'an and science could be seen to complement each other. Seyyed Hossein Nasr asks for the revival of Islamic science. Through a textual analysis of his writings, this study shows that Nasr provides a critique of the Western science and technology, while urging Muslims to study it in depth in order to undertake an authentic critique and to develop a new paradigm to usher in the new golden days of Islam.
\end{abstract}

\section{Introduction}

"The golden days of Islam" has been a subject of passionate debate among the orientalist and the non-orientalist scholars alike. Committed Muslim scholars would look at the "purity of gold" and would consider the period of the Prophet (peace be upon him) and the Khulafä' al-Rāshidūn as the golden period of Islam. The subsequent periods would then be compared with the model and inevitably appear less "pure" - in conformity with the hadith stating that the prophet's generation is "the best", followed by the subsequent generations (Khair al-qurūni qarnī, thumma al-ladhīna yalūnahum, thumma al-ladhīna yalünahum). A second group of scholars however, takes a quantitative approach to the "abundance of gold", irrespective of its quality, and so finds the period of the Abbasid to be the golden period of Islam. This is the period when the Islamic or Muslim civilisation was at its peak in terms of all possible indicators of development. Most orientalists and some Muslim scholars adhere to this school of thought. A third group of scholars, presumably Muslim historians, considers the entire period of Islam until the abolition of the Ottoman caliphate in 1924 as the golden period of Islam: there have always been ups and downs and twists and turns, but nevertheless Islam prevailed; hence it is instructive to look, however briefly, at the entire period in order to draw lessons for the future development of the Muslim Ummah. 


\section{Islamic Civilisation: The Golden Years}

The Prophet Muhammad (pbuh) was sent to a nation steeped in barbarism, in the words of the Qur'an, "to rehearse unto them the signs of Allah, to sanctify them, to teach them the Scriptures and knowledge - who before had been in utter darkness" (62:2-5). The Prophet, finding the Arabs sunk in degrading and sanguinary superstition, taught them belief in Allah (SWT). Seeing them disunited, and engaged in perpetual warfare, he united them through ties of brotherhood, affinity, and justice. The early spread of Islam was perhaps solely due to the Prophet's religious energy and to the firm conviction of his companions. The Prophet brought about a change not only in the religious sphere but also in the political situation and social conditions. The government established by the Prophet was "Shuratic" in nature unlike most of the states and kingdoms of the medieval period; he enunciated a charter of liberty, equality and fraternity in which the rights and duties of the Muslims and the non-Muslims were clearly defined. The intrinsic value of a man was to be judged not by his rank or fortune but by his character and competence. The government was a constitutional, limited government governed in accordance with the first written constitution in the world. Al-Khulafä al-Rāshidūn simply carried forward the principles enunciated by the Prophet and followed in his footsteps. This golden age of Islam showed beyond any reasonable doubt that it is possible to achieve meaningful social restructuring and economic and political development through a political system that is rooted in ethics and morality.

Thus, tawhìd and its concomitant principles of equality, brotherhood, knowledge, justice, and decision by consultation came to play an important role in the history of mankind. Its stage was the globe; its time was for all ages to come, and its dramatis personae a multitude of the people of mankind. While Christendom passed through an age of comparative darkness, a vigorous period of intellectual growth in places like Baghdad, Damascus, and Toledo was under way. From the $9^{\text {th }}$ to the $11^{\text {th }}$ century, the most mighty and active civilisation of the world was Islamic. Hispano-Arab Spain gave the world versatile and worldfamed philosophers, astronomers, mathematicians, mystics and historians. It was a period of intellectual enlightenment and material prosperity and of the territorial expansion of Islamic civilisation.

Decline and decay becomes imminent for those civilisations which, after reaching the zenith of glory, set aside the basic principles of human values and freedom to rule the people at the point of the sword devoid of regard for truth and justice. Decline certainly sets in when a country becomes a dwelling for political fanaticism, wholesale corruption and moral turpitude. It surely falls upon the people when their leaders turn into demagogues and opportunists bent 
upon destroying their competitors in partisan bickering, squabbles and intrigues. History clearly testifies that the civilisations of Babylon and Abbasids were lost in the wealth of legend, because these empires were ruled with ruthless cruelty and wanton oppression. Baghdad, the seat of learning and knowledge and cradle of Islamic civilisation, was crowded with ambitious leaders of Machiavellian dexterity who manoeuvred to retain power. It was consequently brought down by the Mongols. The sack of Baghdad brought about the reckless assassination of thousands of scholars, poets, and writers and the destruction of libraries and colleges, bringing irreparable disaster to Muslim civilisation. With the extermination of men of learning and the destruction of Muslim society, the spirit of inquiry and original research so distinctly associated with Islam's civilisational development was practically destroyed.

Muslims have been searching and writing ceaselessly for ways to break out of this situation, to regain control of their collective lives and to link their past to the future. Some scholars, subscribing to the "secularisation thesis", suggest a Western-style secular state and argue that in course of time religion will disappear (Bell, 1977:306; Breen \& Hayes, 1996; Hadden, 1987). But religion, to their dismay, has not merely survived but, in fact has blossomed (Bouma, 2008; Thomas, 2005). It continues to play a dominant role at national and international levels (May, 2008) as exemplified by the rise of new religious movements and spiritualities (Hunter, 1981; Marty \& Appleby, 1991-c.1995). There are others who advocate a Sharīah-governed society, but who cannot agree upon the model to be implemented. Finally, there are others who seek a synthesis of Islam, nationalism, democracy and modern technical capabilities. Some of these writings reflect biased scholarship, as is generally the case with "Orientalism". Muslim apologists deny the allegations and challenge the malevolent representations of Muslim ideals and aspirations. Some other writings by Muslims are characterised by obduracy and are closed to new methods of critical enquiry.

There also has emerged a group of scholars who seek to engage with the West directly. They proceed from the standpoint that knowledge acquired and disseminated by the West throughout the world was exploitative and aimed at establishing and sustaining Western economic and political control. They argue, however, not to forsake science and education but to pursue it in an "Islamic" way, so as to promote civilisational renewal. This movement is referred to as the "Islamisation of knowledge" project and it has taken many forms. One group of scholars put all their efforts into identifying modern scientific knowledge from the revealed sources, specifically from the Qur'an. A second group of scholars highlight the scientific achievements of the earlier Muslim scholars during the golden days of Islam. Their aim is to highlight the failure of the West to acknowledge the role Muslim scientific achievements played in the rise of 
Western civilisation. They also aim at educating the Muslims about their past and to follow their predecessors in charting a better future.

Finally, a third grouping, and the main focus of this paper, proposes a project which aims at rediscovering and pursuing what is known as the "Sacred Science" or "Religious Science". Seyyed Hossein Nasr has emphasised in all his writings on the necessity of recovering "Religious and Sacred Science" from the traditionalist point of view. After a brief introduction to the "living philosopher", this paper describes Nasr's critique of modernism and modern science and the responses modernism has generated, examines the traditional science, which Nasr fervently aspires to revive, and provides a critique of Nasr's position.

\section{Seyyed Hossein Nasr}

Seyyed Hossein Nasr, an Ismā '̄îl Shī' ite and gnostic thinker, was born on April 7, 1933 in south-central Tehran to an educated family. He received his early education in Tehran where he learnt religion, poetry and classical literature. Nasr went to study physics and mathematics at the prestigious Massachusetts Institute of Technology (MIT) and obtained his B.S. in 1954 with honours. Thereafter, he started to study geology and geophysics at Harvard, but he soon changed the course of his academic studies opting instead to study the history of science and philosophy. Nasr obtained his doctorate in 1958 with specialisation in cosmology and Islamic sciences. His doctoral dissertation was on conceptions of Nature in Islamic thought which was later published under the title An Introduction to Islamic Cosmological Doctrines (1964). During his studies, Nasr became familiar with the writings of F. Schuon and Henry Corbin and was greatly influenced by them. He first served at Tehran University as a professor of history of science and philosophy and also served as a visiting professor at Harvard and other Universities. In 1975, Nasr and Corbin founded the Imperial Academy of Philosophy with the blessings of Empress Farah of Iran. In 1979, Nasr migrated to the United States and taught at several American universities before finally joining the George Washington University, Washington DC in 1984 as the University Professor of Islamic Studies. Nasr is the first Muslim to deliver the prestigious Glifford Lectures at the University of Edinburgh, later published as Knowledge and the Sacred (1981). He is also the recipient of the Templeton Religion and Science Course Award and the only Muslim scholar to have been recognised as a living philosopher through the publication of a volume on Nasr in the Library of Living Philosophers Series (Hahn, Auxier and Stone, 2001).

Seyyed Hossein Nasr speaks and writes from the standpoint of the doctrine and viewpoints of "the philosophia perennis" (perennial philosophy) which is rooted in the metaphysical and the sacred and which, he believes, is valid for all people regardless of time and place since it deals with universal principles. $\mathrm{He}$ 
has argued for the revival of religious values, spirituality and "tradition." Most of his ideas are derived from the scholarship of Rene Guenon and Fritjof Schuon. He is considered to be

One of the leading figures in ... the "neo-traditionist" movement in modern Islam and has contributed enormously to the enrichment of ideas earlier propounded by Rene Guenon. [Moreover] his defense of the "whole and integral tradition of Islam" separates him from other contemporary Shi'ite Muslim thinkers and brings him closer to the mainstream of Islamic thought (Nyang and Ahmad, 1985: 289)

He has written extensively on a variety of subjects including philosophy, religion, spirituality, science and the natural environment. Seyyed Hossein Nasr is a prolific author. The fifty-odd books and monographs and 500 articles produced during 1961 to 1999 can be divided into two broad fields - Islamic studies and the philosophia perennis (Chittick, 2007: ix-xiv). His Science and Civilization in Islam (1968) is praised for clarifying the concept of "Islamic science" and for highlighting the achievements of Islamic scientific tradition in such fields as medicine, astronomy, mathematics, physics, geography, and natural history. Another famous work is his Islamic Science: An Illustrated Study (1976), which defines Islamic science, its philosophical premises, its history and development with clarity. Nasr's analysis of the relationship between Islam and science is found in many of his writings including Islamic Life and Thought (1981), The Young Muslim 's Guide to the Modern World (1993), and The Islamic Intellectual History in Persia (1994). Nasr has been accorded the highest honour of the academic world in the dedication of a volume of The Library of Living Philosophers to his work and thought (Hahn, 2001). Nasr is an eloquent speaker and a highly respected intellectual figure in the Western philosophical world.

\section{Modern Science}

Seyyed Hossein Nasr is specifically concerned with modern science and its implications for humanity. It is this science that needs to be Islamised. However, first and foremost, there is a need to provide an in-depth critique of modernism. To be sure, many modern writers have provided critical analyses of modernism and the paradigm that has been dominant in the West for the past few centuries. These writers, quite justifiably, were concerned that the modern experiment has landed humanity in a pitiable condition to the point of almost irremediable catastrophes. However, these critiques are eclectic and partial. The need is to rely upon the tradition which alone can provide a sure guide for carrying out this critique.

Nasr does not deny the merits of modern science, but he does not regard it as the highest form of knowledge. He appreciates scientific knowledge which is 
based upon rationalism and empiricism but this scientific knowledge occupies a level lower in the hierarchy than religious and Divine truths. He criticises modern science for its being cut off from "the Transcendent, from the immutable principles which in reality govern all things and which are made known to man through revelation in its most universal sense" (Nasr, 1983:164). Science, if it is to serve humanity, must take cognisance of the sacred. This was the way science was practised before the advent of modernity (Nasr, 1993:6). The scientific revolution in Europe brought about a major change in the European philosophical thought which then came to rely solely upon scientific experiment, upon the knowledge of external things based upon empirical data, external experience. It is based upon things that are changeable and impermanent and consequently is devoid of the "essence." Modern science has its roots in philosophical assumptions that characterise the Scientific Revolution of the $16^{\text {th }}$ and $17^{\text {th }}$ centuries.

The Renaissance, Nasr emphasises, initiated the process of secularisation. To Nasr, secularism is an evil force that led to Knowledge becoming "... nearly completely externalised and desacralised, especially among those segments of the human race which have become transformed by the process of modernisation..." (Nasr, 1981:1). Desacralisation, to Nasr, meant the separation of science and knowledge from the homogeneous form of traditional knowledge. This desacralisation of knowledge is the result of the new conception of man as a free earthly being cut off from the total universe of faith of medieval Christianity. Man has become exclusively terrestrial and at home in a newly discovered earth which "he identified as 'the world' and not as nature over which he now felt the sense of greater domination than ever before" (Nasr, 1996: 169). Man is no longer defined by his celestial archetype "but by his individuality, reason, the senses, and corporeality" (Nasr, 1996: 169). Individualism, which made all values human-centred, allied with rationalism, with its reliance solely upon reason as the highest and only authority for the attainment of truth, drove a wedge between philosophy and revelation. The consequence of draining knowledge and intelligence of their sacred character is the emergence of a profane science which is applied in almost all studies. Nasr, considering natural sciences as an integral part of the discourse on Islamisation of knowledge, presents the character of this modern science, which is well-summarised by Ibrahim Kalin.

The first and the foremost characteristics of modern science is that it is secular. It finds no traces of the Divine in the natural order, and it denies any telos or purpose to the universe. It rejects the teleological view of the universe shared by all traditional civilisations. Second, modern science conceives of the universe as a machine which lends itself to the precise methods of analysis and measurement as in physical sciences. Third, it conceives of rationalism and empiricism as the only reliable methods of arriving at truth. Fourth, it presupposes a total separation 
between rescogitans and res extensa, i.e. between the knowing subject and the object to be known. This has given rise, among others, to the epistemological and spiritual alienation of man from his natural environment. Fifth, modern science has adopted the "Promethean view of man", construing man as the measure of all things as against the "Pontifical man", i.e., man as a bridge between heaven and earth. Finally, modern science exploits nature for the sake of power and domination. These traits of modern secular science may be considered its philosophical framework that has led to the demise of the sacred view of the cosmos and is responsible for all the ills of the modern world including the environmental crisis and nuclear warfare (Kalin, 2001:453-458).

Modernism, to Nasr, is a philosophy which rejects the theocentric view of reality. Modernism replaces God with man from the centre of reality. It places special emphasis on the individual and individualism and upon human reason and the senses. Its epistemology is based essentially upon rationalism or empiricism and it judges everything using human values as the ultimate criteria. Modernism is thus characterised by the cluster of humanism, rationalism, thisworldly orientation, empiricism and anthropocentrism. This modernism has weakened not merely traditional Islamic institutions, but, also the fundamentals of the Western Christian tradition. This mode of science or knowledge that has monopolised knowledge since the seventeenth century in the Western tradition is the very negation of the traditional religious worldview. Traditional science is based upon metaphysical principles. It is, therefore, God-centred, theocentric. It considers man to be theomorphic, possessing the faculties not merely of the senses and reason, but also intellect, spiritual intuition, and faith. Modern man, Nasr argues, "in order to gain dominion over the natural environment, has created a situation in which the very control of the environment is turning into its strangulation, bringing in its wake not only ecocide but also ultimately suicide" (Nasr, 2003:94).

\section{Muslim Responses to Modern Science}

Western science and technology have been introduced and accepted by the authorities in the Muslim world, irrespective of the type of regime in power. They have pervaded all aspects of life in the Muslim world. This has resulted in the introduction of secularism and the relegation of the knowledge of Islamic metaphysics somewhere down on the priority list. Consequently, the younger generation of Muslims lack knowledge of many aspects of Islam and instead take glory in discussing intellectual matters in English or French languages. Intellectuals are no less responsible for this sad state of affairs. Muslim scholars have failed to understand the true nature of modern science and its relationship with Islam. 
Muslim scholars, in the early thirteenth/nineteenth century, believed that the effective way to deal with the impact of colonialism on the Muslim world is to modernise Islam. Thus, edicts were passed in the Ottoman Empire, to modernise the Islamic Law of the land. Similar attempts were made in Persia and other areas under European colonial rule. For example, Sir Sayyid Ahmad Khan led the modernisation movement in India. He saw himself as heir of the Mu tazilites (rationalists) stressing the role of reason and science in promoting a good life. In several of his works, he promoted the idea of Muslims and Europeans sharing their heritage of science with each other. To this effect, he founded a Scientific Society in 1867 with the aim of translating Arabic books on natural sciences into English to benefit the Europeans and to translate works on modern science into Urdu for the benefit of Indian Muslims. He also founded the first Muslim university for the Indian Muslim elite, Muhammadan Anglo-Oriental College of Aligarh in 1875, which emulated Cambridge and Oxford universities. In his Qur'anic exegesis, Sir Sayyid proposed a new theology that rejected the notion of conflict between the Qur'an and science (the laws of nature) and refuted the supernatural character of miracles. For this he was bitterly criticised by the 'ulama' ' and was condemned by Ashraf Ali Thanwi (d. 1943) as a heretic (Thanwi 1992, vol. 6:166-85).

Sir Sayyid was followed by Jamal al-Din Astrabadi, known as al-Afghani (1838-1897) whose political goals were very different. Unlike Sir Sayyid who saw the British Empire as the guardian of Muslim interests in India, Afghani was a pan-Islamist, with strong anti-colonial undertones. However, he also showed a keen interest in the modernisation of Islam project and held a critical attitude to the inherited traditions of Islam. A rationalist, Afghani appealed to all Muslims to rely on the principle of rationalism which, he claimed, was the hallmark of Islam. He also advocated the Mu'tazilite doctrine of free will against fatalism. To him, reason and revelation are compatible to each other. Islam cannot contradict reason or science. The Qur'an, to Afghani, provides very general principles; it should not contradict the stipulation of reason and the achievement of science.

In Egypt, Muhammad 'Abduh (1849-1905) attempted modernising Islamic theology by relying significantly on the use of reason. 'Abduh was very much inspired by Comtean positivism which was popular among the educated classes (Hourani, 1983: 138). He was primarily concerned with the corruption of Islam by its rulers throughout history. He saw the need for religious reform because of a gap between the traditional religious education and modern education under European influence. 'Abduh and Afghani have been compared to Martin Luther for their interest in adapting religion to the modern world. Like Luther, Afghani and 'Abduh attacked religious corruption and decaying religious institutions. These modernists were interested in Western science as well as in the revival of the Islamic world hoping that Islam can withstand the onslaught of secular science. 
They argued that science is good and that it is necessary to acquire power and domination and that science originated in Islam only to be taken over by the West to dominate the Muslim world. It is, therefore, necessary to reclaim the heritage, and to repossess science, the hall-mark of Islamic civilisation. The problem with the modernists is that they adopted an ideology prevalent in the Western world and then attached the word Islam to it as a prefix. Therefore, there has emerged a plethora of expressions such as "Islamic democracy", "Islamic socialism" and Islamic economy". Nasr agrees that there is some truth in the argument presented by the Muslim modernists, but they neglect the philosophical assumptions and intellectual background of modern science and knowledge, which has resulted in the loss of knowledge of Islamic metaphysics. Science in Islam was inevitably linked to the sacred. Muslim scientists in the past carried out their research to discover an aspect of the divine reality. Muslims did borrow science from preIslamic Alexandria but they acquired only the elements of "inspired origin" and sidelined the secular and naturalistic aspects of the Graeco-Roman heritage. As an example, Nasr cites Ibn Sina (d. 1037) who developed the legacy of Aristotle and the Islamic philosophy of al-Kindi and al-Farabi.

The 'ulama ', religious scholars, are equally responsible for the flourishing of the profane science in the Muslim world. The 'ulamā' disdained science completely and stood aloof from it. They failed to realise that studying and understanding modern science is a Qur'anic imperative and is also essential for the economic and political development of the Muslims as a community. They equated science with modern science and hence did all they could to preserve the faith against the Western onslaught. They did not provide a critique of modern science on the basis of Islamic criteria as was done by their ancestors in Basra, Baghdad and other centres of learning a thousand years before them. There were few exceptions and Nasr names Mulla Ali Zunuzi, Allamah Taba-tabai, Murtada Mutahhari and others who provided an in-depth criticism of some features of Western science from the Islamic point of view. But by and large, the 'ulama refused to study science. They did help preserve the faith but did not help Muslims to "digest this science and make it part of its own organism through assimilation as well as rejection rather than through her wholesale uncritical swallowing of Western science and technology" (Nasr, 1988:36). This has facilitated the spread of secularism and modern knowledge in the Muslim world.

\section{Nasr and the Project of Islamisation of Knowledge}

Nasr notes that since the Second World War, the crisis brought about by modern science and technology in the West has led a number of Muslims with Western education to search for an alternative to control the damage done by modernisation and Westernisation. They were seriously concerned about the secularising effect 
of the spread of modern science and technology. This awareness has many consequences including attempts at Islamising science along with other branches of knowledge. In the endnote to an article, Nasr claims:

In several of our works written in the 1960 s, we alluded to the central task of Islamising the knowledge that Muslims had encountered in the modern world. This was later taken and discussed by Naquib al Attas and during the last few years became central to the concern of the late Ismail al-Faruqi and a number of other Muslim scholars (Nasr, 1988: 44).

Of the many efforts made in this direction, Nasr was initially very sympathetic to the Islamisation of knowledge project led by Ismail al-Faruqi who, it may be noted in passing, suggested reintegrating Islamic and modern knowledge thus renewing the link between knowledge and values. For al-Faruqi, Islamisation of knowledge meant a systematic reorientation and restructuring of the entire field of human knowledge in accordance with a new set of criteria and categories squarely based on the Islamic worldview (IIIT, 1982: 15). According to al-Faruqi "to recast knowledge as Islam relates to it, is to Islamise it" (IIIT, 1982: 15). This means

... To redefine, and reorder the data, to rethink the reasoning and relating of the data, to reevaluate the conclusions, to re-project the goals and to do so in such a way as to make the disciplines enrich the vision and serve the cause of Islam (IIIT, 1982: 15).

In a talk delivered at MIT, Nasr agreed that Ismail al-Faruqi's Islamisation of Knowledge project "is now very popular" and the monograph published by IIIT with the same title "is now being discussed in educational conferences throughout the Islamic World, [which] is finally going to bear some fruit ... [but] the task is very daunting and difficult one." Subsequently, he has changed his mind asking if Islamisation can be carried out by relying only on one dimension of the Islamic tradition, i.e., the Shari 'ah by neglecting the entire intellectual and spiritual tradition of Islam (Nasr, 2010:105).

\section{Islamic Science}

Nasr extols the virtues of the traditional science which needs to be revived. Nasr believes that knowledge cannot be looked at separately from metaphysical principles. He speaks of a sacred science that needs to be presupposed before approaching the results of modern knowledge. These results need to be observed from the perspective of metaphysical tradition (see Nasr, 1993). Nasr advocates a reconstruction of Islamic scientific thought on the basis of the revealed knowledge. He believes in the existence of a Primordial Tradition that flows directly from an Absolute Truth which has been explained by the adherents of the school of philosophia perennis through the ages. This school of perennial philosophy is associated with the concept of a sacred science based on a universal metaphysics of this Ultimate Truth. 
Nasr provides an outline of the philosophical foundation of a sacred science or Scientia Sacra which

"... is none other than that sacred knowledge which lies at the heart of every revelation and is the center of that circle which encompasses and defines tradition... [T]he twin source of this knowledge is revelation and intellection or intellectual intuition which involves the illumination of the heart and the mind of man and the presence in him of knowledge of an immediate and direct nature which is tasted and experienced, the sapience which the Islamic tradition refers to as "presential knowledge" (al-'ilm alhuựūrî)" (Nasr, 1981:119).

"Scientia sacra can ... speak of God or the Godhead, Allah, the Tao, or even nirvana" (Nasr, 1981:137). Thus, apparently, Nasr considers all religions to be somewhat at the same level. In Islam, Nasr uses the term "sacred" to mean the Divine Reality, the very reality of God who in the Qur'an is named, among others, as al-Quddus. Thus, God is the sacred. He also uses the term "sacred" for things in this world that are related to the sacred. Thus Jerusalem is sacred and is called Bayt al-Muqaddas or Quds. Thus, sacred refers to the God as well as to things that come from Him and are thereby sacralised.

Sacred science, therefore, is founded on metaphysical principles which are derived directly from revelation and are squarely anchored in the principle of unity (tawhild). Tawhi d should be the focus of Muslim scientists. It refers to the "application of metaphysical principles to the macrocosm as well as the microcosm, the natural as well as the human worlds" (Nasr, 1993: 2). Sacred science thus incorporates the physical, the metaphysical, the natural as well as the psychological phenomena. Nasr uses the term scientia sacra or sacred knowledge to express his notion of Islamised knowledge. This is the knowledge that lies at "the heart of every revelation and is the center of that circle which encompasses and defines tradition" (Nasr, 1981:130).

The term sacred, for Nasr, is very intimately connected with the term tradition. To Nasr, tradition means "truths of sacred origin revealed originally ... truths coming from the spiritual domain, coming from God or from Ultimate Reality, speaking metaphysically, with their elaboration and transmission within a historical religious civilisation" (Nasr, 2010: 181). There are thus, two elements in tradition: truths that came from the Divine and the continuity of that tradition through transmission and application of the principles of Divine Origin over the centuries. Thus understood, the traditional natural sciences derive their workethics and methodology and also metaphysical and ontological understanding, "from the principles of Divine revelation because they were rooted in a conception of knowledge according to which the knowledge of the world acquired by man and the sacred knowledge revealed by God were seen as a single unity" (Nasr, 
2003: 93). Nasr describes himself as a traditionalist who is bent upon defending, without being apologetic, the classical view of Islam. The tradition needs to be defended because tradition expounds the truth which means to state the real. Ultimately, Nasr believes that the truth and the real are the same.

\section{What is to be Done?}

Nasr reminds Muslims that they are confronted with a modern science which is not merely ever changing but also tied to power and hence capable of affecting the lives of Muslims in myriad ways. They must confront this science and provide an adequate Islamic answer or response to meet the intellectual challenges posed by modern science. He warns: "If the Muslim world indiscriminately also tries to join the camp of confusion and the process of the destruction of the environment in the name of being in the twenty-first century, I believe such a step will be suicidal" (Iqbal, 2009: 51). Thus, Nasr emphasises the need for Muslims to reconstruct knowledge. According to Nasr, the first step in this direction is for Muslims to realise that they cannot adopt modern scientific knowledge by any means. Attempts have been made in the past, by citing the Qur'anic verses and the hadith (the sayings of the Prophet) to show the similarities between modern scientific knowledge and Islamic undertakings. To Nasr, modern scientific knowledge is not in conformity with the Islamic worldview, and it is not the 'ilm, the knowledge, that the Qur'an obligates the faithful to acquire. Modern science instead is anthropocentric relying exclusively on human reason and empirical data to the exclusion of the sacred and metaphysical foundations of knowledge (Nasr, 1975: 14). What is needed, therefore, is to return to the concept of tawhìd, divine unity (Nasr cited in Kalin, 2001: 451). Tawhìd does not merely refer to the strict unity and oneness of the Creator but refers most importantly to the unity of all phenomena. Tawhìd is relevant not merely for the spiritual, philosophical, and theological concerns but also for the cultivation of natural sciences. Tawhìd requires of men to rediscover the primordial bond between the Creator and the created that has been severed. Muslims must adopt a holistic view of the universe and a holistic epistemology for its scientific study. They must assert the traditional Islamic view on contemporary issues that are currently being debated. This would require a good deal of preparation. In an article published in 2010, Nasr itemises the efforts needed to revive the "sacred science" which emphasises metaphysics. "Metaphysically speaking, the Sacred is that which is totally itself, independent of any other reality, therefore absolute and encompassing every reality that is infinite. These are attributes of the Divine ultimate Reality. So, the Sacred is another way of speaking about the Divine" (Kalin, 2001: 449). Nasr requires of Muslims to do the following for the rehabilitation of the sacred 
science and thus for the renewal of civilisation: One, Muslims must master all the branches of the modern sciences in depth as well as the newly created fields related to these disciplines in their relations to religion, philosophy and social forces. They should be studying these sciences in their applied form as well as their philosophical suppositions and their world views. They must acquire these sciences such that they can speak with an authoritative voice in the modern sciences. However, they must pursue modern science with unwavering faith and attachment to the Islamic worldview and not as second rate Western thinkers without their own distinct intellectual framework.

Two, Muslims must also be deeply steeped in the Islamic intellectual tradition and learn the way in which Muslim scholars in the past made use of the heritage of antiquity and produced a science which served as the basis for the future development of science among Muslims. They must know the epistemology rooted in the Qur'an, and the concept of nature described in the Qur'an. They must know Muslim thinkers and numerous schools of jurisprudence, philosophy and science. They must know how these Muslim sages have conceived the idea of science and nature and how they adopted and adapted the Western science to be in conformity with the Islamic world view. Nasr reminds Muslims that there exists a large amount of materials produced by Muslim scholars written in Arabic, Persian, Turkish, Urdu and other languages so that they do not remain a slave of European languages in the fields of sciences. In other words, these Muslims were interested not merely in Islamising the content of the sciences but also of the languages in which they were expressed. This is admirable since the secularisation of thought is reflected in that of language. It is, therefore, essential for Muslims to learn and benefit from works produced in various Islamic languages.

Three, laced with knowledge of the Western science and the thorough understanding of the Muslim intellectual heritage, Muslims may now proceed to provide a critique of modern science in the light of Islamic teachings. They must first of all be acquainted with the works produced by the Western critics of the modern science and follow these with the criticism of modern science highlighting its essentially agnostic and secularist nature. They must provide a critique of the premises, methodologies, and conclusions of the modern science in the light of the teachings of Islam.

Finally, Muslims must create an Islamic science which would integrate all that is positive in the modern sciences into the Islamic worldview. This Islamic science would incorporate all the factual discoveries of modern science, relate these facts to higher principles and affirm Unity or tawhìd and the purposefulness of all creation. They must create a new paradigm or framework in which tawhìd reigns supreme, where knowledge is sacred whose supreme form is the knowledge of Allah subhānahu wa ta 'āla as summarised in the shahādah, Lā ilāha illa'Llāh. 
In sum, "If the Islamic world is to survive while guarding its authenticity, it must master modern science, criticise it in the light of Islamic teachings, create a paradigm drawn from Islamic sources, and develop a new chapter in the history of Islamic science based upon the earlier Islamic scientific tradition whose history and philosophy must be fully resuscitated" (Nasr, 2010: 67).

\section{Critique}

Nasr's strategy for the civilisational renewal is discomforting for many. He has been criticised for his scathing attack on the philosophical foundations of modern science. His adherence to the concept of the perennial philosophy has also been attacked by orthodox traditional Muslims. He has been severely criticised for his suggestion that all religions are forms of the everlasting truth revealed by God to humankind. Traditional Muslim scholars do not agree that every true revealed religious form expresses something of the absolute.

Nasr's defence of traditional sciences has been criticised by many as nothing but a nostalgic appeal with no real consequences for the current problems surrounding modern science. Ziauddin Sardar provides the harshest criticism of Nasr, using Beatles terminology under the heading "Nowhere Man," inspired by the Beatles. To Zia, Nasr is taking us on a "Magical Mystery Tour," and summarises Nasr's views under the title "Ground Control to Major Tom," after the first line in David Bowie's song Space Oddity (Stenberg, 1996: 269). Major Tom, to Sardar, is an astronaut who is lost in space in a technically defect rocket. Some scholars lament the lack of clear examples/projects where this new "Islamic science" can be shown to be actually taking place. Tabrizi points out that "Islamic science has not been able to demonstrate what an Islamic physics looks like and how different it is from Western physics" (Tabrizi, 1996: 325).

Despite criticisms, Nasr continues to insist on questioning the received meaning of science and provides a new approach for analysing the vexed question of religion and science. His writings on the philosophy of science and his calls for the development of Islamic science received modest public reception. To some of his adherents, Nasr's works have given an increasing salience to the discourse on Islamisation of Science.

\section{Conclusion}

The Muslim experience, in terms of science and technology, consists of a golden age in the tenth through to the thirteenth centuries, a subsequent collapse, and a history of frustration in the twentieth and twenty-first centuries. Muslims experienced European colonialism and the domination of Western science and technology in their lands. In the aftermath of the Second World War, Muslims became acutely aware of their deficiencies in science and technology. 
Muslims for long have been debating the issue of the reconciliation of Islam with science and technology. Some wrongly reject science as being immoral and materialist, others seek, through suitable interpretations of the Qur'an, a reconciliation between revealed truth and physical reality, and still others espouse what is known as the Islamisation of Science.

Seyyed Hossein Nasr defines contemporary Islamic science in terms of humanist values he finds in the Qur'an and the hadith. Inspired by mystical ideals, Nasr articulates the need for an Islamic science free of nuclear energy and devoted to environmental harmony. Writing from the perspective of the perennial philosophical tradition, Nasr exposes various features of the destructive and dehumanising aspects of modern science and technology. With a deep knowledge of the history and philosophy of modern western scientific thought and religions, Nasr argues that Muslims cannot simply emulate western civilisation if they desire to revive the "golden days of Islam." Modern science is a direct challenge to the Islamic worldview. However, Muslims must study Western science in depth in order to provide a genuine critique from an Islamic perspective on the basis of the Islamic intellectual tradition. It is the responsibility of Muslim scholars, intellectuals, and scientists to create an authentic contemporary Islamic science. This is necessary for civilisational renewal. Many Muslims agree with his views, but there are also many who find his alternative to modern science and technology as backward looking and of little benefit to solve the contemporary problems facing the Muslim ummah.

\section{Policy Recommendations}

- Muslims must steep themselves more deeply in the Islamic intellectual tradition and the lives and works of Muslim thinkers and numerous schools of jurisprudence, philosophy and science, as well as the epistemology rooted in the Qur'an, and the concept of nature described in the Qur'an.

- Because of the large amount of materials produced by Muslim scholars that has been written in Arabic, Persian, Turkish, Urdu and other languages Muslims must address themselves to mastering these languages as well as to "Islamising" the content of sciences conveyed in them. It is essential for Muslims to learn and benefit from works produced in various Islamic languages.

- "If the Islamic world is to survive while guarding its authenticity, it must master modern science, criticise it in the light of Islamic teachings, create a paradigm drawn from Islamic sources, and develop a new chapter in the history of Islamic science based upon the earlier Islamic scientific tradition whose history and philosophy must be fully resuscitated" (Nasr, 2010: 67). 


\section{References}

Al-Attas, N. S. 1993. Islam and Secularism. $2^{\text {nd }}$ ed. Kuala Lumpur: ISTAC.

Al-Faruqi, I. 1992. Al-Tawhid: Its Implications for Thought and Life. $2^{\text {nd }}$ ed. Herndon, VA: IIIT.

Bouma, G. D. 2008. "The Challenge of Religious Revitalisation and Religious Diversity to Social Cohesion in Secular Societies.” In B. S. Turner (Ed.), Religious Diversity and Civil Society: A Comparative Analysis. Oxford: The Bardswell Press.

Breen, R., \& Hayes, B. C. 1996. "Religious Mobility in the UK." Journal of the Royal Statistical Society (Series A (Statistics in Society)), 159(3), 493-504. 17 Dr David Radford - Science and the Islamization of Knowledge GCRI Public Lecture 7 August, 2012.

Chittick, William C. (ed.). 2007. "Introduction" in The Essential Seyyed Hossein Nasr. Blookington, IN: World Wisdom.

Hadden, J. K. 1987. "Toward Desacralizing Secularization Theory." Social Forces, 65(3), 587-611.

Hahn, Lewis Edwin, Randall E. Auxier \& Lucian W. Stone (Eds). 2001. The Philosophy of Seyyed Hossein Nasr. Chicago: Open Court.

Hourani, Albert. 1983. Arabic Thought in the Liberal Age 1798-1939. Cambridge: Cambridge University Press.

Hunter, J. D. 1981. "The New Religions: Demodernization and the Protest Against Modernity." In Wilson (Ed.), The Social Impact of New Religious Movements.

IIIT. 1982. Islamization of knowledge: General principles and workplan. Herndon, VA: International Institute of Islamic Thought.

Iqbal, Muzaffar. 2009. Islam, Science, Muslims and Technology, Muzaffar Iqbal in conversation with Seyyed Hossein Nasr. Islamabad: Dost Publication.

Kalin, Ibrahim. 2001. "The Sacred versus the Secular: Nasr on Science" (445-463). In Hahn, Lewis Edwin, Randall E. Auxier \& Lucian W. Stone (Eds). 2001. The Philosophy of Seyyed Hossein Nasr. Chicago: Open Court.

Marty, M. E., \& Appleby, R. S. (Eds.). 1991-(c.1995). Fundamentalism Project. Chicago: University of Chicago.

May, J. D. A. 2008. "Political Religion: Secularity and the Study of Religion in Global Civil Society.” In B. Spalek \& A. Imtoual (Eds.), Religion, Spirituality and the Social Sciences. Bristol: The Policy Press.

Nasr, S. H. 1968. Science and Civilization in Islam. Cambridge: The Islamic Texts Society.

Nasr, S. H. 1976. Islamic Science: An Illustrated Study. London: World of Islam Festival Publishing Company.

Nasr, S. H. with Ramin Jahanbegloo. 2010. In search of the sacred: A conversation with Seyyed Hossein Nasr on his life and thought. California: Praeger.

Nasr, S. H. 1968. Science and Civilization in Islam. Cambridge: Harvard University Press.

Nasr, S. H. 1976. Islamic Science: An Illustrative Study. London: World of Islam Festival Trust.

Nasr, S. H. 1981. Knowledge and the Sacred: The Glifford Lecture. Edinburgh: Edinburgh University Press. 
Nasr, S. H. 1983. "Reflections on Islam and Modern Thought." Journal of Studies in Comparative Thought, Summer-Autumn, Volume 15, Nos. 3 and 4 (Double Issue).

Nasr, S. H. 1993. The Need for a Sacred Science: An Intellectual Defence of the Tradition. Albany: State University of New York Press.

Nasr, S. H. 1996. Religion and the Order of Nature: The 1994 Cadbury Lectures at the University of Birmingham. Oxford: Oxford University Press.

Nasr, S. H. 2003. "Contemporary man between the Rim and Axis." In Mehrdad M. Zarandi (Ed.), Science and the Myth of Progress. Bloomington: World Wisdom. 93-94.

Nasr, S. H. 2010. "Islam and the Problem of Modern Science”, Islam \& Science, 8, no. 1: 63-74.

Nyang, S. S. and Mumtaz Ahmad. 1985. "The Muslim Intellectual Émigré in the United States." Islamic Culture, 59, no. 3 (July): 277-90.

Stenberg, L. 1996. The Islamization of Science: Four Muslims Positions Developing and Islamic Modernity (Vol. 6). Lund: Religionhistoriska avdelnungen, Lunds universitet.

Tabrizi, B. G. 1996. “Is Islamic Science possible?” Social Epistemology, 10(3-4), 317-330.

Thanawi, A. A. 1992. Imdad al-fatawa, 6 vols. Karachi: Darul Isha'at.

Zaidi, A. H. 2006. "Muslim Reconstructions of Knowledge and the Re-enchantment of Modernity." Theory, Culture \& Society, 23(6), 69-91.

\section{Note}

* Abdul Rashid Moten is Professor of Political Science at the International Islamic University Malaysia. His latest edited book is Government and Politics in Malaysia (Cengage Learning, 2013). He is the Editor-in-Chief of Intellectual Discourse, the flag-ship journal of the International Islamic University Malaysia. 